\title{
Giant petrosal aneurysm of the internal carotid artery causing stroke in a young man
}

\author{
Veysel Akgun, ${ }^{1}$ Sebahattin Sari, ${ }^{1}$ Samet Verim, ${ }^{2}$ Ugur Bozlar ${ }^{1}$
}

${ }^{1}$ Department of Radiology, Gulhane Military Medical Faculty, Ankara, Turkey ${ }^{2}$ Department of Radiology, Mevki Military Hospital, Ankara, Turkey

\section{Correspondence to} Dr Veysel Akgun, akgunveysel@yahoo.com
To cite: Akgun V, Sari S, Verim $\mathrm{S}$, et al. BMJ Case Rep Published online:

[please include Day Month Year] doi:10.1136/bcr-2013009593

\section{DESCRIPTION}

A 22-year-old man was referred to our centre after an acute infarction in the right insula and basal ganglia region had been revealed by diffusion MRI performed for left hemiparesis. Carotid Doppler ultrasonography was normal; however, imaging of the cervical and cranial arteries with CT angiography revealed a $2.2 \times 2.7 \mathrm{~cm}$ aneurysm in the petrous portion of the right internal carotid artery (ICA) with a peripheral thrombus (figure 1). The patient was referred to the interventional radiology for treatment.

The patient underwent emergency angiography that showed an aneurysm involving the petrous portion of the right ICA (figure 1). Endovascular stent was deployed successfully without any neurological deficit. Follow-up digital subtraction angiography, 3 months later, demonstrated complete obliteration of the aneurysm without parent artery occlusion.

Petrous carotid aneurysms are rare lesions that are likely to be in congenital origin. ${ }^{1}$ Petrous carotid aneurysms are usually large, and fusiform in shape and they may contain chronic thrombus.
They produce various signs and symptoms like headache, nasal congestion and midfaces pain and otological manifestations like conductive and sensorineural hearing loss and tinnitus. Further, rupture as an initial manifestation can occur in approximately $25 \%$ of cases. ${ }^{2}$

Petrous aneurysms can be visualised in CT and MRI. They usually appear as destructing the petrous bone oriented along the carotid canal with well-corticated expansion of it. The relevant differential diagnosis would comprise glomus jugulare or a high-riding jugular bulb. Finally, these lesions can be treated effectively by endovascular or surgical occlusive procedures.

\section{Learning point}

Petrous aneurysms appear as enhancing vascular lesions expanding the petrous bone oriented along the carotid canal. The relevant differential diagnosis would comprise glomus jugulare or a high-riding jugular bulb.
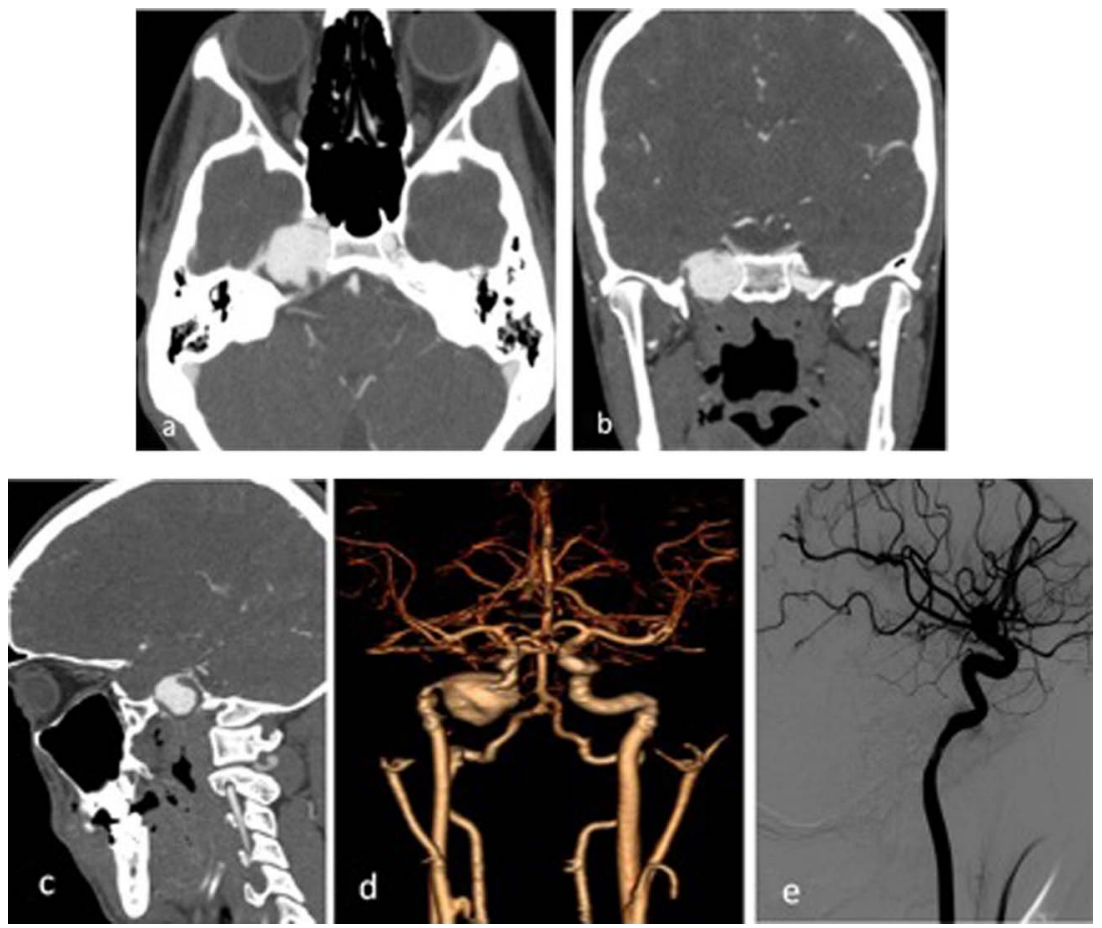

Figure 1 Axial (A), coronal (B) and sagittal (C) reformatted and coloured three-dimensional volume rendered CT angiography images show a wide-necked saccular aneurysm arising from the anterior curve of the petrous segment of the carotid artery. Follow-up digital subtraction angiography image (E) shows complete thrombosis of aneurysm 3 months later. 
Contributors OF was involved in conception, design, analysis, interpretation of data and drafting of the manuscript. NF acquired the data, analysed and interpretedthe data. SD was involved in acquisition of data and critical revision of manuscript. JB and PB critically reviewed and edited the manuscript. VP was involved in conception, design, analysis and interpretation of data and drafting of the manuscript. All the authors approved the final draft of the manuscript.

Competing interests None.

Patient consent Obtained.

Provenance and peer review Not commissioned; externally peer reviewed.

\section{REFERENCES}

1 Halbach VV, Higashida RT, Dowd CF, et al. Aneurysms of the petrous portion of the internal carotid artery: results of treatment with endovascular or surgical occlusion. AJNR Am I Neuroradiol 1990;11:253-7.

2 Tanaka H, Patel U, Shrier DA, et al. Pseudoaneurysm of the petrous internal carotid artery after skull base infection and prevertebral abscess drainage. AJNR Am J Neuroradiol 1998;19:502-4.

Copyright 2013 BMJ Publishing Group. All rights reserved. For permission to reuse any of this content visit http://group.bmj.com/group/rights-licensing/permissions.

BMJ Case Report Fellows may re-use this article for personal use and teaching without any further permission.

Become a Fellow of BMJ Case Reports today and you can:

- Submit as many cases as you like

- Enjoy fast sympathetic peer review and rapid publication of accepted articles

- Access all the published articles

- Re-use any of the published material for personal use and teaching without further permission

For information on Institutional Fellowships contact consortiasales@bmjgroup.com

Visit casereports.bmj.com for more articles like this and to become a Fellow 